\title{
Does the new public management contribute to improving the performance of obstetric care in Mexico public hospitals?
}

\author{
¿Contribuye la nueva gestión pública a mejorar el desempeño de la atención \\ obstétrica en los hospitales públicos de México?
}

\author{
Belkis Aracena Genao ${ }^{1}$, René Leyva Flores ${ }^{1 *}$, María del Rocío Soto Flores ${ }^{2}$ \\ ${ }^{1}$ Instituto Nacional de Salud Pública, México \\ ${ }^{2}$ Instituto Politécnico Nacional, México
}

Received July 24, 2018; accepted January 18, 2019

Available online January 24, 2019

\begin{abstract}
In pursuit of higher performance in the Public Administration, the Mexican government implemented the New Public Management (NPM) model in 2008, with the aim of correcting deficiencies in its public services - including those of the Ministry of Health $(\mathrm{MoH})$-. In ten years of work under the new model, no information has been provided on the effects of NPM on the performance indicators, such as effectiveness and efficiency, of government institutions. The present study had the objective to analyze the impact of the NPM on the effectiveness and efficiency of MoH care facilities. Effectiveness was evaluated as the proportion of hospital discharges (HD) indicating a recovery diagnosis, and efficiency as the average length of hospital stays, modeled with survival analysis and local kernel regression methods. Data analyzed pertained to a time series of 16.5 million obstetric HD (64\% of total discharges) produced from 2000 to 2015. The results revealed high levels of effectiveness ( $98 \%$ of HD with recovery diagnosis) and efficiency (an average hospital stay of 1.74 days), before and after NPM. The consistently high performance throughout the period analyzed, indicate that $\mathrm{MoH}$ hospitals had attained optimal effectiveness and efficiency levels prior to the NPM implementation. The indistinctive impact of the public management reform may suggest that NPM was applied as a blanket solution without considering institutional specificities.
\end{abstract}

JEL code: H83, M11, D73, D24, I18

Keywords: New public management; Effectiveness; Efficiency; Public health services; Mexico

* Corresponding author.

E-mail address: rene.leyva@insp.mx (R. Leyva).

Peer Review under the responsibility of Universidad Nacional Autónoma de México. 


\section{Resumen}

En la búsqueda de mejorar el desempeño de la administración pública, el gobierno mexicano implementó, en 2008, la Nueva Gestión Pública (NGP). Con este modelo se pretendía corregir las deficiencias en la provisión de servicios públicos, incluidos los otorgados por la Secretaría de Salud. A diez años de su implementación, se desconoce la contribución de la NGP en el desempeño de los hospitales de la Secretaría de Salud de México. El presente estudio analizó el impacto de la NGP en la efectividad y eficiencia (dos de los principales indicadores de desempeño hospitalario) de la atención obstétrica (la principal actividad hospitalaria -64\% del total de egresos hospitalarios-) en la Secretaría de Salud. Los datos analizados corresponden a una serie temporal de 16,5 millones de egresos hospitalarios obstétricos producidos entre 2000 y 2015. La efectividad se midió como la proporción de egresos con diagnóstico de recuperación y la eficiencia como el promedio de día estancia. El cambio en la eficiencia, antes y después de la implementación de la NGP, se modeló con análisis de sobrevida y Regresión Kernel. Los resultados revelaron altos niveles de efectividad ( $98 \%$ de egresos hospitalarios con diagnóstico de recuperación) y eficiencia (una estancia hospitalaria promedio de 1,74 días), antes y después de NGP.El alto rendimiento, constante durante todo el período analizado, indica que los hospitales de la Secretaría de Salud alcanzaron, y conservaron, niveles óptimos de efectividad y eficiencia antes y después de la implementación de la NGP. La falta de impacto de esta reforma en la gestión pública puede sugerir que el NGP se aplicó como una solución general sin considerar las especificidades institucionales.

Código JEL: H83, M11, D73, D24, I18

Palabras clave: Nueva gestión pública; Efectividad; Eficiencia; Servicios públicos de salud; México

\section{Introduction}

For decades, ineffectiveness and inefficiency in public services have caused substantial concern worldwide, with government institutions often viewed as incapable of responding to the constantly changing needs of society (World Bank, 2016). A number of proposals have thus been formulated with the aim of transforming the administrative model of governments into one grounded in the principles of private management (Marvel, 2016).

Salient among these proposals, the New Public Management (NPM) model emerged in the late 1970s as a means of abating the widespread economic crisis, and was rapidly adopted by the reform agendas of most OECD countries (Gruening, 2001). The NPM model proposes the utilization of private sector management methods and tools as a pathway to improving public sector effectiveness and efficiency, among others (Siltala, 2013). Its implementation requires paradigmatic and operational shifts in the role of government based on neoliberal approaches. From a paradigmatic viewpoint, NPM requires governments to participate in the economy as facilitators, rather than competitors, of private activity (World Bank, 2016). Operationally, it proposes that governments transform their institutions into outcome-driven 
organizations that abandon bureaucratic schemes in order to focus on effectiveness and efficiency as the cornerstones in the production of social services for those unable to afford them privately (World Bank, 2016).

The NPM model was adopted by developing countries in response to the unsatisfactory performance of their public institutions. As indicated by World Bank surveys, government bodies are the object of global distrust (World Bank, 2016) manifested in claims of inefficiency in the management of public resources and incompetence in meeting the needs of populations, particularly of the most vulnerable groups. Improving management in government institutions has thus become a priority worldwide (World Bank, 2016), with NPM proposed as a means of remedying ineffectiveness and inefficiency (CLAD, 1998; World Bank, 2016).

Pursuant to international agreements in favor of public management reforms via nationwide action plans, the Mexican Government approved a national NPM reform process under the 2006 Budget and Fiscal Responsibility Law (MoF, 2006), administered through the Ministry of Finance and Public Credit (SHCP by its Spanish initials). The Chamber of Deputies of the Mexican Congress instituted this new model in 2008 with the aim of transforming traditional resource allocation into a dynamic operation focused on the outcomes of policies and programs (Curristine, Lonti, \& Joumard, 2007). Following the reform, the Federal Government, including the Mexican Ministry of Health $(\mathrm{MoH})$, incorporated NPM mechanisms as a pathway to more effective and efficient public services.

Looking for understanding the thinking behind the Mexican government decision to implement the NPM, we carried out a literature review. This review had the aim to look for empirical evidence about the effects of the NPM on the health care system performance. We restricted the search to the terms New Public Management and health, in English and Spanish, in the Medline, Pubmed, Lilacs-Bireme, Scielo, and Redalyc databases, 2000-2018. We reviewed the abstracts wich mentioned New Public Management in their title, and, when these abstracts sugested an analysis of the NPM on health care system performance, the articles were enterely reviewed.

At the moment that Mexico implemented NPM, in 2008, the global literature on health care system performance related to NPM was scarce. In addition, the evidence generated, after the NPM implementation in our country, shows null or negative effects. Thus, a study conducted in Spain, concluded that there is no evidence that the NPM contributes to improving the technical efficiency of hospitals in Madrid (Alonso, Clifton, \& Díaz-Fuentes, 2015). Another study, also carried out in Spain, analyzed the effects of the NPM on the status of the medical profession, concluded that the NPM causes inequalities related to the conformation of social stratus into the medical profession (Cascon-Pereira, Kirkpatrick, \& Exworthy, 2017). In Portugal, Nunes and Ferreira (2018) found that NPM instead of improve health system performance increase the health care costs (Nunes \& Ferreira, 2018). In Norway, a 
study titled "The nurse-patient relationship in the New Public Management era, in public home care: A focused ethnography", concluded the New Public Management could affect (in a negative way) the quality and meanings of the relationship between nurses and patients cared in Norwegian public home (Strandas, Wackerhausen, \& Bondas, 2018). In Sweden a NPM strategy to shorten queues to healthcare, consisting in pay out to the county councils for reducing the queues for first visit, resulted in longer queues for return visits, affecting the patients with chronical or severe diseases (Hansson, 2014).

A group of Australian researchers also tested a NPM strategy in the South of Australia. The authors explored the consequences on the nursing work of imposing rounding as a risk reduction strategy. The rounding looked for to "place the patient at the centre of the ward routine by taking care back to the patient, it involves nurses carrying out regular and standardized checks, on all patients at set intervals to assess and manage their fundamental care needs". Health system managers looked for to improve quality, efficiency and productivity, but by the contrary, rounding increased call bells from bedridden patients, moreover it negatively affected the nurse-patient relationships (Willis et al., 2016). Another study carried out in Australia and New Zealand determined that the culture of austerity that includes healthcare budget cuts "impacted on the quality of patient care and nursing work, as well as contributing to missed care" (Willis, Carryer, Harvey, Pearson, \& Henderson, 2017). An study published in Mexico in 2009 that included all Mexican public administration areas, concluded that the NGP has not had the expected impact on the improvement of the performance of the state public administrations measured in terms of their contribution to the quality of life and the satisfaction of the citizens (Martínez-Vilchis, 2009). With hardly any existing empirical evidence or literature on its functionality (Levy, 2010) to guide an informed decision, the Mexican Government adopted the NPM model relying on the decisions of the majority of developed OECD countries.

Ten years after local implementation, the impact of the new model on the performance (effectiveness and efficiency) of the Mexican public sector was still unknown. The present study therefore sought to contribute knowledge on the subject by evaluating the effectiveness and efficiency of Mexican public health services before and after NPM implementation.

The $\mathrm{MoH}$ is a vast and complex institution. To mention only a few of its principal functions, this institution manages the national Health Care System, provides financing for health activities, and delivers services. Our analysis focused specifically on the delivery of obstetric services, which account for roughly $64 \%$ of total hospital discharges (HDs) from $\mathrm{MoH}$ facilities. This area of health care has been drawing increased attention from researchers worldwide, with maternal mortality internationally classified as a major public health problem. The pervasiveness of pregnancy-related deaths and complications, particularly in developing countries, reflects social inequality, poor health care, and limited access to health 
services. The present study explored obstetric-care performance at $\mathrm{MoH}$ facilities before and after the introduction of the NPM model in 2008 (2000-2015). It analyzed the trend in HDs with a recovery status as a measure of effectiveness $(\mathrm{MoH}, 2017)$ and the average length of stays (LoS) of obstetric patients in MoH hospitals as a measure of efficiency (DGED, 2013).

\section{Methods}

Study design and setting

Based on an observational, retrospective time series design, we quantified the effectiveness and efficiency of $\mathrm{MoH}$ facilities operating under the framework of the NPM model. Analysis considered the health status of obstetric-care patients at the time of HD and the average LoS required to produce a HD. Indicators were assessed before and after the implementation of the NPM model. Previous studies have reported post-admission mortality and unplanned readmissions (Davis et al., 2013)effectiveness, equity (E3, yet these data were unavailable in the analysed databases.

Data were drawn from hospital-care databases compiled by the MoH Directorate General of Health Information (DGIS by its Spanish initials) (DGIS, 2015). Of the 25.8 million observations registered from 2000 to 2015 , we analyzed 16.5 million obstetric cases concerning women of reproductive age (between 10 and 54 years).

\section{Statistical analysis}

We calculated averages, standard deviations, and proportions by type of variable. HDs were grouped, according to the type of care, into three categories: obstetric complications, vaginal deliveries and cesareans, and estimated by status: recovery (full recovery or remission) and other (voluntary discharge, referral to another health care facility, death, and unspecified) (Eurostat, 2017b). Temporary descriptions were formulated under stacked columns. Given the high concentration of HDs with a recovery status (98.3\% during the 16 years analyzed), we considered only central tendency (average) and dispersion (standard deviation (SD) measures by type of care provided.

Regarding efficiency, analysis excluded LoS beyond ten days, with evidence (Campbell, Cegolon, Macleod, \& Benova, 2016) showing that this is normally the maximum in-hospital time for obstetric patients. Moreover, LoS beyond this timeframe accounted for only $0.25 \%$ of total obstetrics cases in the analyzed databases. We performed survival analysis in order to compare the temporal relationship between HD and average LoS before and after NPM implementation. Given the retrospective nature of our study, follow-up comprised all subjects until occurrence of the event of interest (HD). Analysis did not include censored (exact survival 
time unknown) or truncated (delayed entry of patient into the study time scale) data. As the likelihood of HDs was assumed to occur independently, the Kaplan-Meier survival function was estimated (Kleinbaum \& Klein, 2005). Survival analysis is a statistical procedure used for "analyzing data where the outcome variable is the time until the occurrence of an event of interest. The event can be death, occurrence of a disease, marriage, divorce, etc. The time to event or survival time can be measured in days, weeks, years, etc. For example, if the event of interest is heart attack, then the survival time can be the time in years until a person develops a heart attack" (Hosmer, Lemeshow, \& May, 2011).

Average LoS (outcome variable) was modeled via kernel-weighted local polynomial regression methods (Welsh, 1996) using the Epanechnikov function and a polynomial degree of 3 (Deng \& Chu, 2010); its trend was modeled as a function of time ( $t=$ year of occurrence of a HD). Kernel weighted local regression estimate nonparametric explanatory variables effects (Yu \& Lin, 2008). This procedure is adequate to represent (graphically) the non-linear relationship between an explanatory factor (years of following) and the result (average of hospital stay). All analyses were performed on Stata version 14.

\section{Results}

Over the period analyzed, HDs for obstetric complications and vaginal deliveries increased 156\% (from 256347 in 2000 to 656152 in 2015) and 59.6\% (from 345850 in 2000 to 552 117 in 2015), respectively, but dropped 25.8\% (from 52464 in 2000 to 38949 in 2015) for cesarean deliveries (Figure 1). We also observed changes in the proportional distribution of HDs by type of obstetric care provided: from 2000 to 2008, vaginal deliveries represented $48.7 \%$ of all obstetric HDs, followed by obstetric complications (44.3\%) and cesarean deliveries (7\%). Conversely, from 2009 to 2015, that is, following NPM implementation, obstetric complications rose to $50.4 \%$ of obstetric HDs, followed by vaginal (45.2\%) and cesarean (4.4\%) deliveries (Figure 1).

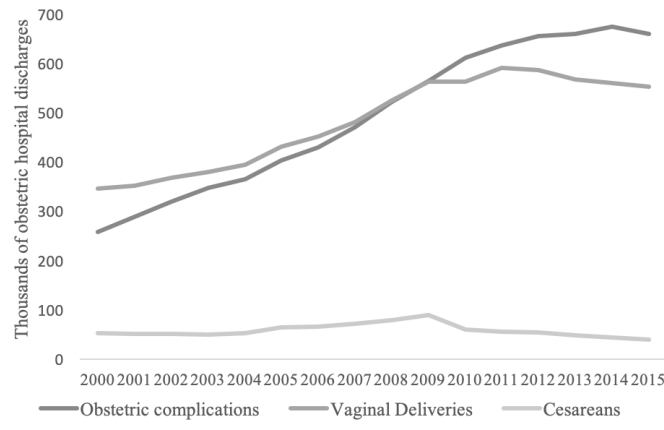

Figure 1. Trend in obstetric hospital discharges by type of care provided at Ministry of Health facilities (Mexico, 2000-2015)

Source: Prepared by the author with data from the General Directorate of Health Information (2000-2015). 
Effectiveness in the production of obstetric services, measured as the proportion of HDs with a full recovery health status, reached $98.5 \%$ of total cumulative HDs from 2000 to 2015, barely fluctuating between a minimum of $98 \%$ in 2000 and a maximum of $98.8 \%$ in 2011 (Figure 2). As expected, the highest level of effectiveness (99.5\%) was observed in vaginal deliveries and the lowest (97.4\%) in obstetric complications. Care for cesarean deliveries proved highly effective, with $99.3 \%$ of HDs resulting in recovery.

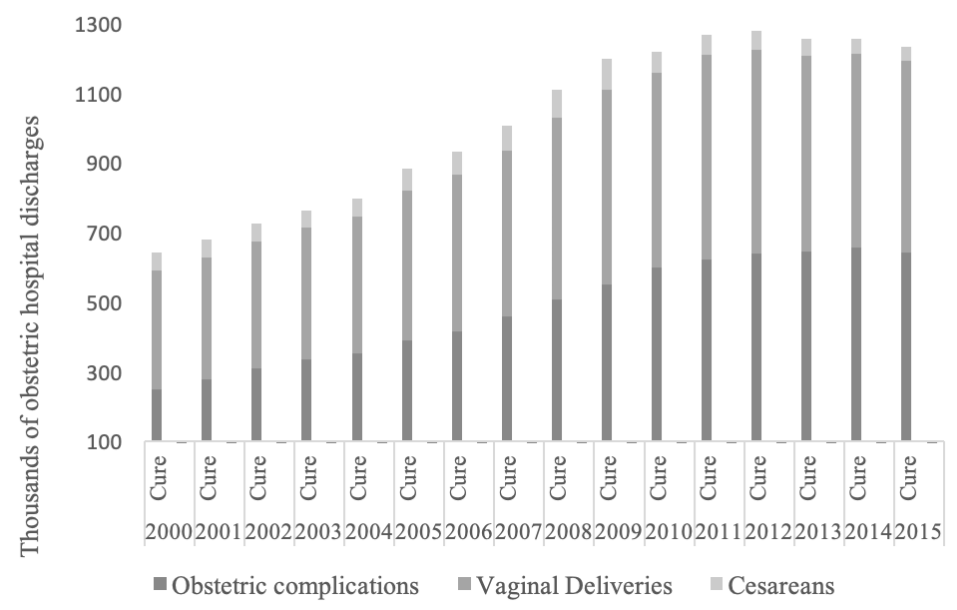

Figure 2. Hospital discharges due to health improvement, 2000-2015

Source: Prepared by the author with data from the General Directorate of Health Information (2000-2015).

Table 1 displays the number of HDs and average LoS by year and type of care. Over the study period, the average LoS culminating in a HD - regardless of the type of care provided - was 1.74 days ( $\mathrm{SD}, 0.93$ days). When considering average LoS by type of care, vaginal deliveries required only 1.15 days ( $\mathrm{SD}, 0.55$ days) to produce a HD, as opposed to 2.20 days (SD, 1.03 days) in the case of cesarean deliveries. Temporal analysis indicated a highly homogeneous distribution of LoS over time: 2000 registered the longest (1.80 days; SD, 0.95 days) and 2004 the shortest LoS averages (1.68 days; SD, 1.03 days) (Table 1). 


\section{B. Aracena Genao, et al. / Contaduría y Administración 65(1) 2020, 1-14}

http://dx.doi.org/10.22201/fca.24488410e.2019.2109

Table 1

Obstetric hospital discharges and average length of hospital stays by type of obstetric care provided at Ministry of Health facilities (Mexico, 2000-2015)

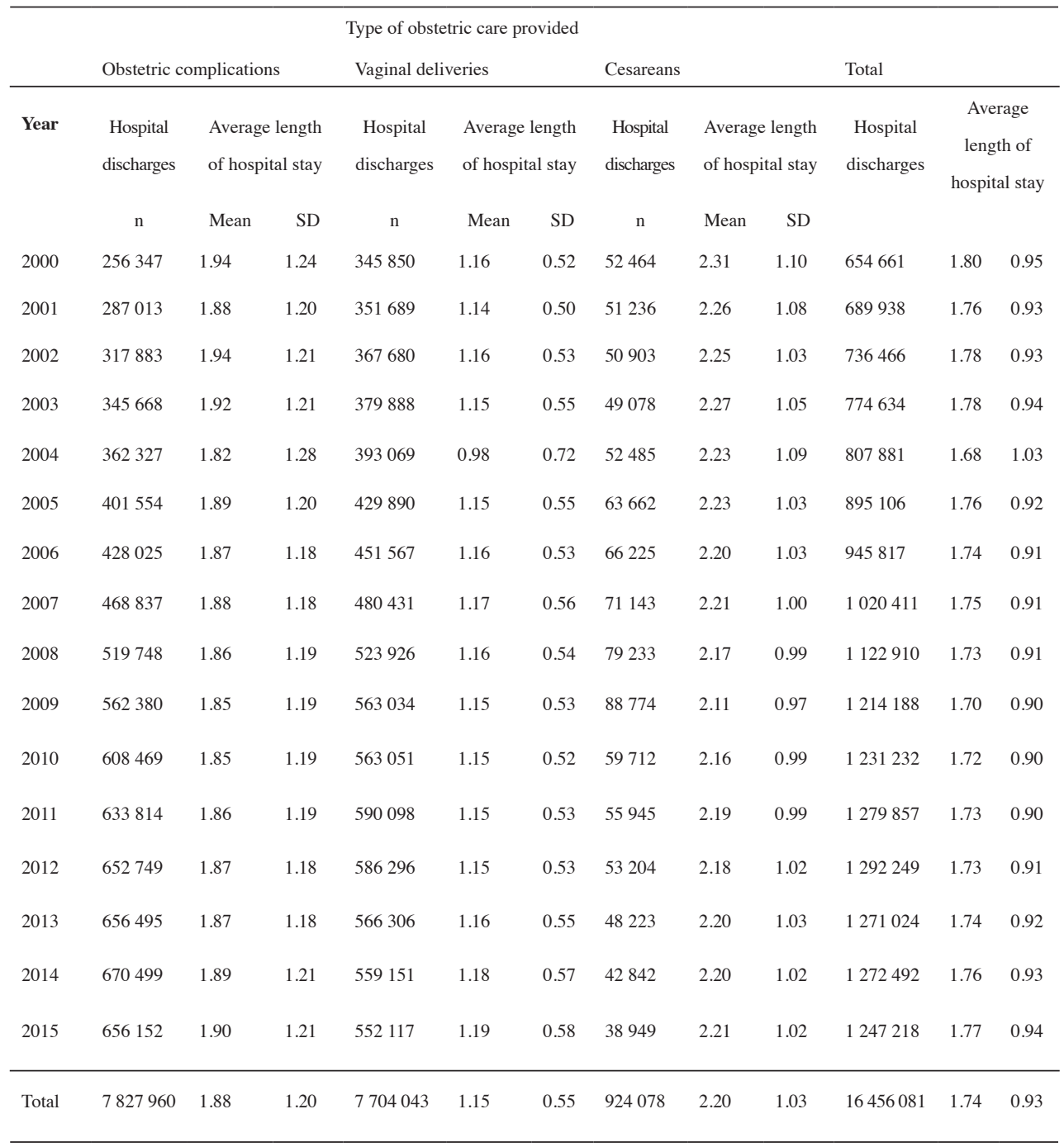

Source: Prepared by the author with data from the General Directorate of Health Information (2000-2015).

In order to explore the relationship between HDs and LoS, we performed survival analysis and found homogeneous results in the number of days required to produce a HD, irrespective of the type of obstetric care provided (Figure 3). Regarding cesarean delivery services, 
the probability of a HD on the same day of admission was zero, both before and after NPM implementation. However, the cumulative probability of a HD on the fourth day slightly increased following NMP implementation ( $75 \%$ versus $63 \%$ ).

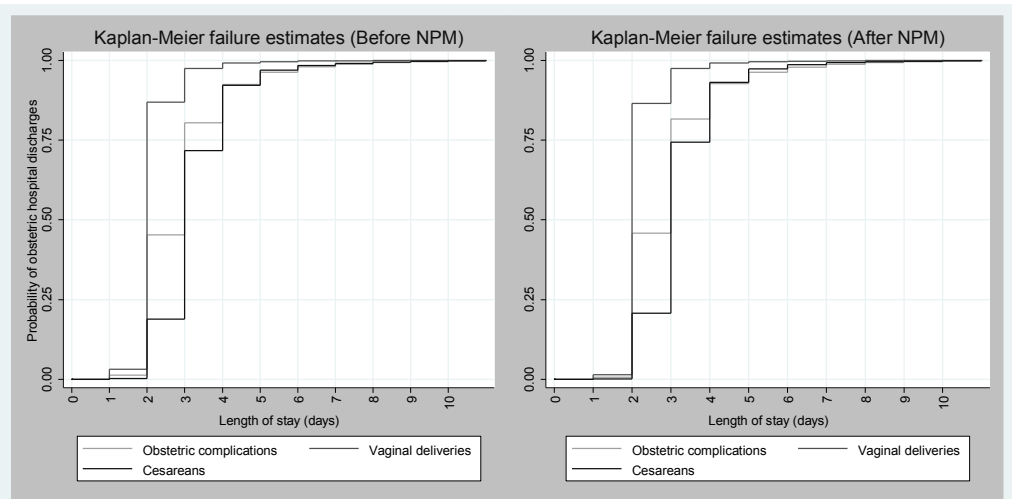

Figure 3. Daily cumulative probability of obstetric hospital discharges before and after the implementation of the New Public Management (NPM) model by the Ministry of Health (Mexico).

Source: Prepared by the author with data from the General Directorate of Health Information (2000-2015).

Local polynomial smoothing (Figure 4) showed an average LoS of 1.54 days, with minor variations at the edges of the study period reaching a minimum in 2000 (1.52) and a maximum in 2015 (1.58).

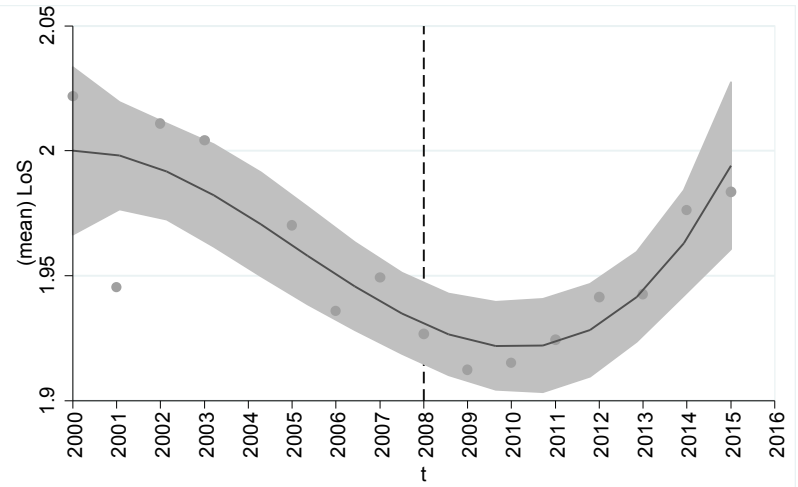

kernel $=$ epanechnikov, degree $=3$, bandwidth $=44.36$, pwidth $=66.55$
Figure 4. Temporary distribution of average length of stay $(\mathrm{LoS})$ for obstetric care in Ministry of Health facilities (Mexico).

Source: Prepared by the author with data from the General Directorate of Health Information (2000-2015). 


\section{Discussion}

Mexico, similarly to various other countries worldwide, has implemented numerous strategies in order to improve the performance of its institutions, the most recent being the NPM model in 2008. NPM was adopted with the purpose of correcting effectiveness and efficiency limitations commonly encountered across government organizations. Actions launched under the theoretical guidelines of the NPM model included the installation of a performance evaluation system and a procedure for continuous monitoring of budget formulation and execution towards the development of quality, effective and efficient public services (Lapsley, 1999; Nuti, Seghieri, \& Vainieri, 2013).

Implementation of the NPM model has called for considerable investments in the transformation of processes, installation of technology, and training of key personnel, among others. While the exact amounts disbursed are unavailable, in 2017, the SHCP provided an estimate of US\$ 8,784.8 million. Expenditures have included actions to support the new budget process, enhance institutional efficiency, and improve public management and services (SHCP, 2017). This notwithstanding, no changes have been observed in the effectiveness and efficiency indicators.

The results presented here indicate that the administration of public health services related to obstetric care was already highly effective - even exceeding the national target of $93.3 \%(\mathrm{MoH}, 2017)$ - prior to NPM implementation, and remained stable (98\%) throughout the period analyzed. Likewise, as regards efficiency, analysis yielded an average of 1.75 days for HDs prior to NPM implementation, lower than the numbers reported in the literature (Campbell et al., 2016; Ford, Algert, Morris, \& Roberts, 2012; Kim, Kim, Han, \& Park, 2017). Our findings therefore demonstrate that obstetric services at $\mathrm{MoH}$ facilities had achieved optimum levels of effectiveness and efficiency since before NPM implementation, leaving little room for improvement over the period analyzed. According to the indicators analyzed in this study, the commonly held perception of ineffective and inefficient public health services is unfounded, at least with regard to obstetric care. It is important to bear in mind, however, that the indicators selected, although internationally used to measure hospital performance (Eurostat, 2017a; Sarkies et al., 2015), may not have been sufficiently sensitive to obstetric service events. Furthermore, the frequent and generalized "anti-public sector" messages spurring a negative perception of public institutions should be taken into account (Marvel, 2016).

Also of relevance is the fact that the effectiveness and efficiency of public health services may have benefited from strategies adopted before NPM implementation to reduce obstetric risks and improve maternal health (Secretaría de Salud, IMSS, \& ISSSTE, 2009). Likewise, they may have been boosted by the introduction of demand-related 
mechanisms designed to facilitate access to health services, such as the Social Protection System in Health. Our findings may also reflect the presence of favorable changes in the health-seeking behavior of the Mexican population, e.g., a growing awareness of obstetric risks and of the need to detect symptoms and seek care opportunely. Finally, the generalized perception of inadequate public services that triggered the NPM reform may have referred to aspects other than effectiveness or efficiency. These may have included, inter alia, limited access to services, inadequate coverage, insufficient human and material resources, unavailable supplies, barriers to care-seeking, and unsatisfactory interpersonal relationships with staff (Secretaría de Salud et al., 2009).

Mexico decided to institute (2002) and implement (2008) NPM amidst national and global economic crises that were shaking its socioeconomic and administrative structures. Although the capacity of the NPM model was questioned as a strategy to meet the challenges of public administration (Levy, 2010), very little empirical evidence (Alonso, Clifton, \& Díaz-Fuentes, 2013) existed at the time of implementation, and reservations were based on theoretical arguments and macro analyses rather than on specific circumstances. Unavailable evidence compounded by the inertia of public administrations characteristic of developing countries may have accounted for the adoption of NPM despite the fact that developed countries had experienced important failures (Simonet, 2015). The implementation of the NPM model in Mexico reflects a lack of analysis and disregard for indicators existing within the government system. It also shows that decision-making is often driven by a political eagerness to comply with sweeping international covenants (Sarker, 2006) rather than by a rigorous look at local performance. The Mexican Government needs to develop greater knowledge, more in-depth analysis and sound judgments before making decisions, particularly those of nationwide scope.

\section{Conclusions}

In agreement with previous studies (Alonso et al., 2015), we have found no evidence to sustain that the provision of obstetric care in $\mathrm{MoH}$ facilities in Mexico is ineffective or inefficient. With optimal levels of effectiveness and efficiency already existing in this context prior to NPM implementation, it can be affirmed that this model did not improve performance. It follows, then, that the organizational processes and strategies that did contribute to high effectiveness and efficiency in the public health institutions assessed in this study should be identified, strengthened, disseminated, and replicated, while understanding that the predominance of excellence in private administration is a myth (UNDP Global Centre for Public Service Excellence, 2015). It is necessary to continue generating empirical evidence - such as that provided here - regarding the impact of the NPM model on the organization 
and functioning of government institutions. Moreover, good practices that have produced evidence of success should be exploited in order to better understand the dynamics and enhance the performance of government institutions. This is indispensable for stimulating and achieving organizational changes according to existing contexts and social needs.

Most of the studies identified in the literature review have a theoretical-conceptual approach, without evidence of processes or results of NPM implementation; and those who report empirical evidence use qualitative procedures that seek to understand the process and results related to the NPM. In the Mexican context is necessary to carry out researches focusing on determine the NPM effects on other health system areas, but also on other public administration sectors.

\section{Declaration of Conflicting Interests}

The authors declare no potential conflicts of interest with respect to the research, authorship, and/or publication of this article.

\section{Funding}

The authors received no financial support for the research, authorship, and/or publication of this article. 


\section{References}

Alonso, J. M., Clifton, J., \& Díaz-Fuentes, D. (2013). Did New Public Management Matter? An empirical analysis of the outsourcing and decentralization effects on public sector size. Public Management Review, 17(5), 18. http://doi.org/10.1080/14719037.2013.822532

Alonso, J. M., Clifton, J., \& Díaz-Fuentes, D. (2015). The impact of New Public Management on efficiency: An analysis of Madrid's hospitals. Health Policy, 119, 8. http://doi.org/10.1016/j.healthpol.2014.12.001

Campbell, O. M. R., Cegolon, L., Macleod, D., \& Benova, L. (2016). Length of Stay After Childbirth in 92 Countries and Associated Factors in 30 Low- and Middle-Income Countries: Compilation of Reported Data and a Cross-sectional Analysis from Nationally Representative Surveys. PLoS Med., 13(3), 24. http://doi.org/10.1371/ journal.pmed.1001972

Cascon-Pereira, R., Kirkpatrick, I., \& Exworthy, M. (2017). [The status of the medical profession: reinforced or challenged by the new public management?]. Gac Sanit, 31(3), 273-275. http://doi.org/10.1016/j.gaceta.2016.07.023

CLAD. (1998). A New Public Management for Latin America. (Available in: http://www.rrojasdatabank.info/ unpan000163.pdf). (Reviewed date: 18/04/2017).

Curristine, T., Lonti, Z., \& Joumard, I. (2007). Improving Public Sector Efficiency: Challenges and Opportunities. OECD Journal on Budgeting, 7(1), 42.

Davis, P., Milne, B., Parker, K., Hider, P., Lay-Yee, R., Cumming, J., \& Graham, P. (2013). Efficiency, effectiveness, equity (E3). Evaluating hospital performance in three dimensions. Health Policy, 112(1-2), 9. http://doi. org/10.1016/j.healthpol.2013.02.008

Deng, W. S., \& Chu, C. K. (2010). On study of kernel regression function polygons. Journal of Nonparametric Statistics, 12(5), 13. http://doi. org/10.1080/10485250008832824

DGED. (2013). Manual de Indicadores para Evaluación de Servicios Hospitalarios (Manual of Indicators for Evaluation of Hospital Services). Mexico: (Available in: http://www.dged.salud.gob.mx/contenidos/dess/descargas/ ind_hosp/miesh.pdf.). (Reviewed date: 17/11/2017)

DGIS. (2015). Bases de datos sobre egresos hospitalarios (Databases on hospital discharges). (Available in: http:// www.dgis.salud.gob.mx/contenidos/basesdedatos/std_egresoshospitalarios.html) (Reviewed date: 08/12/2017)

Eurostat. (2017). Main statistical findings. Average length of hospital stay for in-patients. Statistics Explanied. (Available in: http://ec.europa.eu/eurostat/statistics-explained/index.php/Hospital_discharges_and_length_of_ stay_statistics). (Reviewed date: 16/11/2017)

Ford, J. B., Algert, C.-S., Morris, J. M., \& Roberts, C. L. (2012). Decreasing length of maternal hospital stay is not associated with increased readmission rates. Aust NZ J Public Health, 36(5), 5. http://doi.org /10.1111/j.17536405.2012.00882.x

Gruening, G. (2001). Origin and theoretical basis of New Public Management. International Public Management Journal, 4, 25.

Hansson, S. O. (2014). Medical ethics and new public management in Sweden. Camb Q Healthc Ethics, 23(3), 261-267. http://doi.org/10.1017/s0963180113000868

Hosmer, D. W., Lemeshow, S., \& May, S. (2011). Applied Survival Analysis: Regression Modeling of Timeto-Event Data (2 Ed.). New Jersey: Wiley.

Kim, S. J., Kim, S. J., Han, K. T., \& Park, E. C. (2017). Medical costs, Cesarean delivery rates, and length of stay in specialty hospitals vs. non-specialty hospitals in South Korea. PLOS ONE, 12(11), 11. http://doi.org/10.1371/ journal.pone. 0188612

Kleinbaum, D. G., \& Klein, M. (2005). Survival Analysis: A Self-Learning Test (Springer Ed. 2nd ed.). New York: Springer. Lapsley, I. (1999). Accounting and the New Public Management: Instruments of Substantive Efficiency or a Rationalising Modernity? Finacial Accountability \& Management, 15(3), 7. http://doi.org/10.1111/1468-0408.00081

Levy, R. (2010). New Public Management: End of an Era? Public Policy and Administration, 25(2), 7. http://doi. org/10.1177/0952076709357152 
Martínez-Vilchis, J. (2009). La nueva gerencia pública en México. Una medición de su intensidad e impactos en las entidades del país. Convergencia, 16(49), 28.

Marvel, J. D. (2016). Unconscious Bias in Citizens' Evaluations of Public Sector Performance. Journal of Public Administration Research And Theory, 16. http://doi.org/10.1093/jopart/muu053

MoF. (2006). Ley Federal de Presupuesto y Responsabilidad Hacendaria (Federal Budget and Liability Law). Mexico: (Available in: http://www.diputados.gob.mx/LeyesBiblio/ref/lfprh/LFPRH_orig_30mar06.pdf). (Reviewed date: 02/12/2017).

MoH. (2017). Porcentaje de egresos hospitalarios por mejoría y curación (Percentage of Hospital Discharges Due to Improvement and Cure). Mexico: (Available in: http://www.hraev.salud.gob.mx/contenidos/Transparencia/ Descargas/2017/E023_Ind_2_Proposito_FICHA_TECNICA_2017.pdf.) (Reviewed date: 08/03/2017).

Nunes, A. M., \& Ferreira, D. C. (2018). The health care reform in Portugal: Outcomes from both the New Public Management and the economic crisis. Int J Health Plann Manage. http://doi.org/10.1002/hpm.2613

Nuti, S., Seghieri, C., \& Vainieri, M. (2013). Assessing the effectiveness of a performance evaluation system in the public health care sector: some novel evidence from the Tuscany region experience. Journal of Management \& Governance, 17(1), 11. http://doi.org/10.1007/s10997-012-9218-5

Sarker, A. E. (2006). New public management in developing countries An analysis of success and failure with particular reference to Singapore and Bangladesh. International Journal of Public Sector Management, 19(2), 25. http://doi.org/10.1108/09513550610650437

Sarkies, M. N., Bowles, K. A., Skinner, E. H., Mitchell, D., Haas, R., Ho, M., Salter, K., May, K., Markham, D., O’Brien, L., Plumb, S. \& Haines, T. P. (2015). Data Collection Methods in Health Services Research: Hospital Length of Stay and Discharge Destination. Applied Clinical Informatics, 6, 14. http://doi.org 10.4338/ACI-2014-10-RA-0097

Secretaría de Salud, IMSS, \& ISSSTE. (2009). Convenio General de Colaboración Interinstitucional para la Atención de las Emergencias Obstétricas. México: (Available in: http://cnegsr.salud.gob.mx/contenidos/descargas/SMP/ ConvenioEO.pdf.) (Reviewed date: 02/11/2017).

SHCP. (2017). Fiscalización a la Gestión Pública. Función Pública. ¿Cómo gasta? (Available in: http://www.transparenciapresupuestaria.gob.mx/es/PTP/programas\#consultas). (Reviewed date: 12/03/2018).

Siltala, J. (2013). New Public Management: The Evidence-Based Worst Practice? [English]. Administration \& Society, 45(4), 26. http://doi.org /10.1177/0095399713483385

Simonet, D. (2015). The New Public Management Theory in the British Health Care System: A Critical Review. Administration \& Society, 47(7), 25. http://doi.org/10.1177/0095399713485001

Strandas, M., Wackerhausen, S., \& Bondas, T. (2018). The nurse-patient relationship in the New Public Management era, in public home care: A focused ethnography. J Adv Nurs. http://doi.org/10.1111/jan.13850

UNDP Global Centre for Public Service Excellence. (2015). Is the Private Sector more Efficient? A cautionary tale. (Available in: http://www.undp.org/content/dam/undp/library/capacity-development/English/Singapore\%20 Centre/GCPSE_Efficiency.pdf). (Reviewed date: 12/03/2018).

Welsh, A. (1996). Robust Estimation of Smooth Regresion and Spread Functions and their Derivatives. Statistica Sinica, 6(1996), 20.

Willis, E., Carryer, J., Harvey, C., Pearson, M., \& Henderson, J. (2017). Austerity, new public management and missed nursing care in Australia and New Zealand. J Adv Nurs, 73(12), 3102-3110. http://doi.org/10.1111/jan.13380

Willis, E., Toffoli, L., Henderson, J., Couzner, L., Hamilton, P., Verrall, C., \& Blackman, I. (2016). Rounding, work intensification and new public management. Nurs Inq, 23(2), 158-168. http://doi.org /10.1111/nin.12116

World Bank. (2016). The Governance Global Practice supports client countries to help them build capable, efficient, open, inclusive, and accountable institutions. Governance. (Available in: http://www.worldbank.org/en/topic/ governance/overview). (Reviewed date: 02/02/2018).

Yu, Z., \& Lin, X. (2008). Nonparametric Regression Using Local Kernel Estimating Equations for Correlated Failure Time Data. Biometrika, 95(1), 15. 